Article

\title{
Accelerated Hermeticity Testing of Biocompatible Moisture Barriers Used for the Encapsulation of Implantable Medical Devices
}

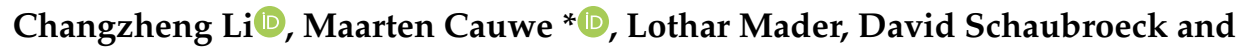 \\ Maaike Op de Beeck * \\ Centre for Microsystems Technology (CMST), imec and Ghent University, Technologiepark 126, 9052 Gent, \\ Belgium; changzheng.li@ugent.be (C.L.); Lothar.Mader@UGent.be (L.M.); David.Schaubroeck@UGent.be (D.S.) \\ * Correspondence: Maarten.Cauwe@imec.be (M.C.); Maaike.OpdeBeeck@imec.be (M.O.d.B.); \\ Tel.: +32-9264-6601 (M.C.); +32-9264-5364 (M.O.d.B.)
}

Received: 28 November 2019; Accepted: 25 December 2019; Published: 26 December 2019

\begin{abstract}
Barrier layers for the long-term encapsulation of implantable medical devices play a crucial role in the devices' performance and reliability. Typically, to understand the stability and predict the lifetime of barriers (therefore, the implantable devices), the device is subjected to accelerated testing at higher temperatures compared to its service parameters. Nevertheless, at high temperatures, reaction and degradation mechanisms might be different, resulting in false accelerated test results. In this study, the maximum valid temperatures for the accelerated testing of two barrier layers were investigated: atomic layer deposited (ALD) $\mathrm{Al}_{2} \mathrm{O}_{3}$ and stacked $\mathrm{ALD} \mathrm{HfO} / \mathrm{Al}_{2} \mathrm{O}_{3} / \mathrm{HfO}_{2}$, hereinafter referred to as ALD-3. The in-house developed standard barrier performance test is based on continuous electrical resistance monitoring and microscopic inspection of $\mathrm{Cu}$ patterns covered with the barrier and immersed in phosphate buffered saline (PBS) at temperatures up to $95^{\circ} \mathrm{C}$. The results demonstrate the valid temperature window to perform temperature acceleration tests. In addition, the optimized ALD layer in combination with polyimide (polyimide/ALD-3/polyimide) works as effective barrier at $60{ }^{\circ} \mathrm{C}$ for 1215 days, suggesting the potential applicability to the encapsulation of long-term implants.
\end{abstract}

Keywords: temperature acceleration test; valid temperature window; moisture barrier; biocompatible encapsulation; $\mathrm{ALD} \mathrm{HfO}_{2} / \mathrm{Al}_{2} \mathrm{O}_{3} / \mathrm{HfO}_{2}$; polyimide

\section{Introduction}

Conventional implantable electronic devices are often packaged in materials such as titanium, Ti alloys, and glass, resulting in reliable but hard and bulky devices. Since device miniaturization, softness and flexibility are important evolutions, and alternative packaging with polymer materials is getting more attention [1-5]. Replacing those hard materials with soft polymers has two major advantages. First, flexibility of the total device can be achieved. As a result, its mechanical properties are closely matched with the mechanical properties of the targeted soft tissue or organ. This also leads to increased comfort for the patient. Second, smaller and flexible devices can reduce scar tissue formation and foreign body reaction (FBR) [6,7]. In general, the encapsulation should realize a hermetic enclosure of the device, using only materials which are biocompatible and biostable. To ensure hermeticity, barrier layers have to be selected carefully. Polymers such as polyimide, polydimethylsiloxane (PDMS), and parylene types are well known for their use in the development of flexible or stretchable implantable electronic [8-10]. However, these polymers do not meet the stringent barrier requirements (very limited diffusion of water, ions, and molecules) to act as barrier layers for long-term implantation [11-13]. Hence the polymers have to be combined with extra diffusion barriers, 
such as thin films of biocompatible metal oxides $\left(\mathrm{Al}_{2} \mathrm{O}_{3}, \mathrm{SiO}_{2}\right.$ and $\left.\mathrm{HfO}_{2}\right)$ [14], deposited by atomic layer deposition (ALD).

ALD is a technique for ultrathin film deposition, enabling a very high control of the film composition, step coverage, and thickness, due to the advantages of the sequential, self-limiting reactions in an ALD process. This results in a thin conformal layer with extremely low pinhole density [15-18]. Due to its reliable deposition process and very low water vapor transmission rate (WVTR), $\mathrm{Al}_{2} \mathrm{O}_{3}$ is the most readily studied thin film used for corrosion protection of steel and moisture/oxygen diffusion protection in organic light-emitting diodes (OLED) [19-21]. The WVTR $\left(\mathrm{g} / \mathrm{m}^{2}\right.$ day) is the flux density of water vapor through a substance (Fick's law of diffusion), which is generally used for the evaluation of barrier layers. It must be mentioned that WVTR tests (in accordance with the ASTM F1249 test method, using Mocon's AQUATRAN ${ }^{\circledR}$ Model 1 instrument) of barrier layers with a WVTR below $10^{-4} \mathrm{~g} / \mathrm{m}^{2}$ day are very time consuming and can only be measured one sample at the time [22]. In addition, the actual lifetime of a device cannot be readily determined solely based on the WVTR of its protective barrier layers.

Although $\mathrm{ALD} \mathrm{Al}_{2} \mathrm{O}_{3}$ is a good barrier against water vapor, ions, and other gases, direct contact with aqueous solutions results in degradation due to hydrolysis [23-25]. To avoid the hydrolysis of $\mathrm{Al}_{2} \mathrm{O}_{3}$ in aqueous solutions, capping the $\mathrm{Al}_{2} \mathrm{O}_{3}$ layer with more chemically stable oxides, such as $\mathrm{SiO}_{2}$ or $\mathrm{HfO}_{2}$, has been reported [24,26]. In 2017, we showed that capping an $\mathrm{Al}_{2} \mathrm{O}_{3}$ layer with $\mathrm{HfO}_{2}$ on both sides (ALD-3) and sandwiching it between two biphenyltetracarboxylic dianhydride and paraphenylenediamine (BPDA-PPD) polyimides (hereinafter referred to as PI) layers results in thin films with a very low WVTR at 100\% relative humidity $(\mathrm{RH})$ (decrease with a factor of 8000 compared to the bare PI layer) [4].

Alternative techniques to evaluate the quality of the ALD layer are porosity inspection and electrochemical impedance spectroscopy (EIS) of an underlying Cu layer. Although an ALD layer is theoretically pin-hole free, very small pore defects are observed which can lead to leakage paths in the barrier layers [27]. Porosity inspection of the $\mathrm{ALD} \mathrm{Al}_{2} \mathrm{O}_{3}$ by $\mathrm{Cu}$ electroplating or $\mathrm{Cu}$ wet etching are practical methods to evaluate the quality of the ALD layers [18]. Monitoring the changes in the thickness or roughness of the $\mathrm{ALD} \mathrm{Al}_{2} \mathrm{O}_{3}$ layer when the layer is soaked in an aqueous environment enables us to study the dissolution of $\mathrm{Al}_{2} \mathrm{O}_{3}[23,25]$. However, all the approaches above do not show how long the $\mathrm{ALD} \mathrm{Al}_{2} \mathrm{O}_{3}$ can perform as a good diffusion barrier when soaked in aqueous solution.

EIS is a non-destructive, high sensitivity test method to monitor the degradation of coating layers exposed to aqueous solutions at different temperatures [28]. In our previous study, this method was employed to monitor the degradation of tested barriers [29]. However, EIS tests are time consuming and labor intensive, especially when testing a large quantity of samples. Therefore, the development of an easier, faster, and automated method to screen and evaluate long-term stability and hermeticity of barrier layers through accelerated temperature testing is also important.

When testing hermetic barriers for long-term implantation, there is an important timing problem. Testing at $37^{\circ} \mathrm{C}$ takes much too long. Hence, accelerated testing at elevated temperatures is necessary. The Arrhenius equation for prediction of the acceleration effects is well known [30,31]. As a rule of thumb, it is often assumed that the lifetime of a barrier under test is reduced by a factor of 2 per $10{ }^{\circ} \mathrm{C}$ increase in test temperature [9,31-33]. However, the acceptable temperature elevation is limited, since the failure mechanisms that are expected to occur at $37^{\circ} \mathrm{C}$ must be identical to the ones encountered at higher temperatures. Therefore, it is important to determine the maximum test temperature for a particular device in order to perform a valid accelerated test and to derive the specific acceleration factor.

PI has been used as a flexible substrate and carrier for implantable medical devices for a long time, and its non-(cyto)toxicity has been proven in many in vitro and in vivo studies [7,14,34-39]. PI was selected because of its high thermal stability, making it compatible with the thermal ALD processes performed at elevated temperature at $250{ }^{\circ} \mathrm{C}$. Verplancke et al. recently developed a PI encapsulated active high-density transverse intrafascicular micro-electrode probe to interface with the peripheral nervous system [40]. Parylene $\mathrm{C}$ and $\mathrm{Al}_{2} \mathrm{O}_{3}$ bilayer encapsulation was applied to Utah electrode 
array-based neural interfaces for chronic implantation [41]. By sandwiching the ALD-3 layer between PI layers, the problem of the non-flexibility of thin metal oxide layers can be tackled. Finally, $\mathrm{Al}_{2} \mathrm{O}_{3}$ and $\mathrm{HfO}_{2}$ are biocompatible and can therefore be used as barrier materials for the encapsulation of implants [42-44].

In the present work, we test the degradation of bare $\mathrm{Cu}$ meanders, as well as $\mathrm{Cu}$ meanders coated with $\mathrm{ALD} \mathrm{Al}_{2} \mathrm{O}_{3}$, ALD-3, PI, and PI/ALD-3/PI barriers by a resistance monitoring method. The aim of the present work is to study the maximum acceleration temperature for a given test barrier and to derive the corresponding acceleration factor. As part of this investigation, the protection against corrosion by various ALD thin films and PI combined with ALD-3 is evaluated.

\section{Materials and Methods}

\subsection{Fabrication of $\mathrm{Cu}$ Meander Patterns}

A Cu layer with a thickness of $1 \mu \mathrm{m}$ was deposited via plasma magnetron sputter coating on $5 \times 5 \mathrm{~cm}^{2}$ glass substrates, using a thin TiW layer to obtain good adhesion. Narrow U-turn Cu meanders of different widths were used (30,40, and $50 \mu \mathrm{m}$ width) with a total length $\sim 25 \mathrm{~cm}$ for each meander. To create the patterned $\mathrm{Cu}$, contact photolithography techniques were used, followed by $\mathrm{Cu}$ and TiW wet etching and resist stripping. The width and thickness of the obtained $\mathrm{Cu}$ patterns were verified by an optical microscope (Zeiss Stemi 2000C, Oberkochen, Germany) and non-contact optical profiler (WYKO NT3300, Plainview, NY, USA), respectively.

\subsection{Fabrication of Barrier Layers: $\mathrm{ALD} \mathrm{Al}_{2} \mathrm{O}_{3}$ and $\mathrm{HfO}_{2}, \mathrm{PI}$}

Both the $\mathrm{Al}_{2} \mathrm{O}_{3}$ and $\mathrm{HfO}_{2}$ layers were deposited in an ALD Savannah system from Ultratech (Waltham, MA, USA), using a thermal ALD process at $250{ }^{\circ} \mathrm{C}$. For the single $\mathrm{Al}_{2} \mathrm{O}_{3}$ layer, a thickness of $20 \mathrm{~nm}$ was selected. In the case of the ALD-3 barrier, a stack of $8 \mathrm{~nm} \mathrm{HfO}_{2}, 20 \mathrm{~nm} \mathrm{Al} \mathrm{O}_{3}$, and again $8 \mathrm{~nm} \mathrm{HfO} 2$ was used, as shown in Figure 1a,b. These ALD layers were deposited directly on the $\mathrm{Cu}$ patterns, or combined with a polymer (PI) layer, as described below.

PI2611 from HD Microsystems was spin coated to obtain a $\sim 5 \mu \mathrm{m}$ thick PI layer. A single coating of PI was used as protection of the patterned $\mathrm{Cu}$, which was compared to a stack of PI/ALD-3/PI, as shown in Figure 1c,d. A cross-section of the PI/ALD-3/PI obtained by focused ion beam scanning electron microscopes (FIB-SEM) is shown in Figure 1e,f. The thickness of the bottom PI layer was $5.30 \mu \mathrm{m}$, and the top PI layer was $5.16 \mu \mathrm{m}$. The ALD-3 layer sandwiched between the two PI layers was $37 \mathrm{~nm}$.

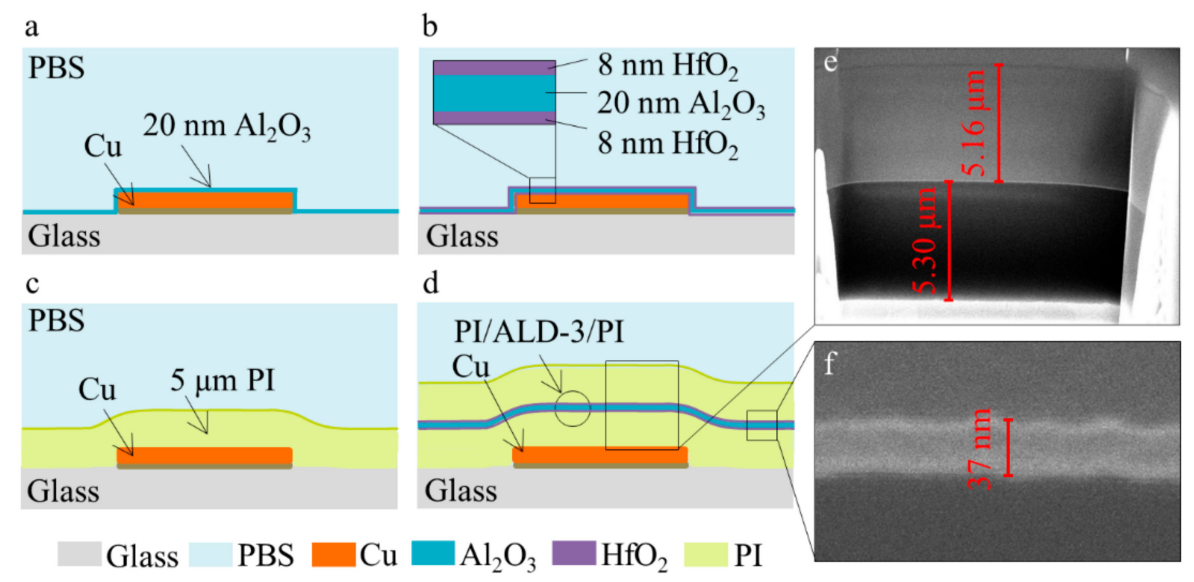

Figure 1. Cross section schematic of barriers: (a) atomic layer deposited (ALD) $\mathrm{Al}_{2} \mathrm{O}_{3}$, (b) $\mathrm{HfO}_{2} / \mathrm{Al}_{2} \mathrm{O}_{3} / \mathrm{HfO}_{2}$ (ALD-3), (c) polyimide (PI), and (d) PI/ALD-3/PI. The cross-section of PI/ALD-3/PI obtained by FIB-SEM: (e) thickness of PI layers and (f) thickness of ALD-3. 


\subsection{Experimental Setup}

$\mathrm{Cu}$ meander patterns were covered with the barrier materials under test and submerged in phosphate buffered saline solution (PBS). The corrosion delay results in an enhanced lifetime of the $\mathrm{Cu}$ structures, which was used as a figure of merit to evaluate the performance of the barriers. To enable immersion of the $\mathrm{Cu}$ patterns, a fluid container was made by gluing a glass ring on the test substrate using silicone glue. The insulating ALD layer and polymer layers were removed from the $\mathrm{Cu}$ solder pads outside the glass ring and connectors were soldered to connect the samples to the resistance measurement system, as shown in Figure 2.

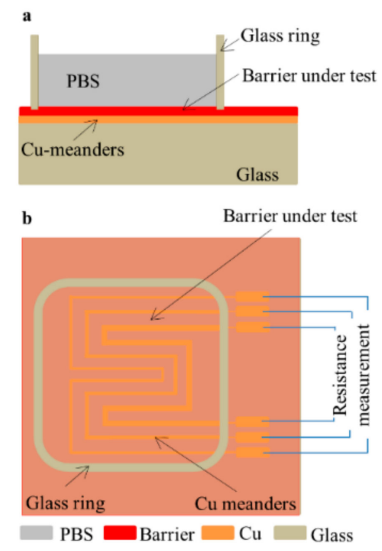

Figure 2. Schematic of soaking test setup: (a) cross-section view; (b) top view.

The $\mathrm{Cu}$ soaking tests were performed in ovens with temperatures ranging from $21^{\circ} \mathrm{C}$ to $95^{\circ} \mathrm{C}$. Temperature variations from sample to sample were minimized to $\pm 0.5^{\circ} \mathrm{C}$ by placing all test samples on the same shelf inside the oven. This was confirmed using thermocouple measurements. For the $\mathrm{Cu}$ soaking test, $15 \mathrm{~mL}$ of PBS (Sigma Aldrich, St. Louis, MI, USA) was injected in the cylindrical glass container. Subsequently, the container was sealed with Kapton tape to limit evaporation. Degradation of the $\mathrm{Cu}$ by corrosion was monitored by measuring the resistance of the meanders every 5 min using a switching system with an integrated multimeter (Keithley 3700A, Beaverton, OR, USA).

\subsection{Acceleration Factor}

In general, the lifetime of samples decreases with increasing soaking temperature. The Arrhenius acceleration factor $\left(A_{\mathrm{T}}\right)$ between the lifetime at reference temperature and the lifetime at tested temperature $\mathrm{T}$ is:

$$
A_{\mathrm{T}}=X_{\mathrm{T}} / X_{\text {ref }}=\left(\left(R_{\mathrm{f}}-R_{0}\right) / L_{\mathrm{T}}\right) /\left(\left(R_{\mathrm{f}}-R_{0}\right) / L_{\text {ref }}\right)=L_{\text {ref }} / L_{\mathrm{T}}
$$

where $X_{\mathrm{T}}$ is the degradation speed of the test set at accelerated temperature, in $\Omega \cdot$ day $^{-1} ; X_{\text {ref }}$ is the degradation speed of the test set at the reference temperature, in $\Omega \cdot$ day $^{-1} ; R_{\mathrm{f}}$ is the resistance when meanders fail, in Ohm; $R_{0}$ is the initial resistance of the meanders, in Ohm; $\mathrm{L}_{\text {ref }}$ is the lifetime of meanders at a reference temperature; $L_{T}$ is the lifetime of meanders at an accelerated temperature $T$ $\left({ }^{\circ} \mathrm{C}\right)$. Both lifetimes are expressed in days. Since our tests were related to the use of an implantable device, the reference temperature was $37^{\circ} \mathrm{C}$.

\section{Results and Discussion}

Thin $\mathrm{Cu}$ meander patterns on glass were selected as test structures. $\mathrm{Cu}$ is interesting due to its fast corrosion rate when immersed in PBS $(\mathrm{pH}=7.4)$. The corrosion can be easily monitored by measuring the resistance of the $\mathrm{Cu}$ patterns immersed in PBS at elevated temperatures. In doing so, different barriers deposited on the $\mathrm{Cu}$ meanders were tested and evaluated: 
- Uncoated bare $\mathrm{Cu}$ meanders as reference;

- $\quad \mathrm{ALD} \mathrm{Al}_{2} \mathrm{O}_{3}(20 \mathrm{~nm})$;

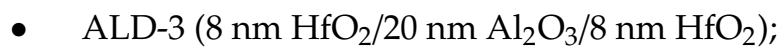

- PI;

- $\quad \mathrm{PI}+\mathrm{ALD}-3+\mathrm{PI}$.

Schematic illustrations of the build-up of these barriers can be found in Figure 1a-d.

The resistance of the meanders remains stable when the barrier works effectively to stop water, ions, and oxygen permeation, while it increases fast when the barrier loses its functionality. Due to the change in conductivity of the $\mathrm{Cu}$ with temperature, we defined the resistance of meanders when soaked for $1 \mathrm{~h}$ as initial resistance $\left(R_{0}\right)$. A Cu meander fails when its resistance reaches three times the initial resistance $\left(3 R_{0}\right)$, as shown in Figure S1. This criterion is somewhat arbitrary and is mainly motivated by the sharp increase in resistance occurring at this point, which reduces the variability from sample to sample. While corrosion of the $\mathrm{Cu}$ is already ongoing for some time at this moment, the period of quick $\mathrm{Cu}$ corrosion is short compared to the lifetime of the barrier. The average time to failure of samples was defined as the meanders' lifetime.

\subsection{Evaluation of the Corrosion of Bare $\mathrm{Cu}$ Meanders}

The average lifetime of the bare $\mathrm{Cu}$ meanders with a width of 30,40, and $50 \mu \mathrm{m}$ soaked in PBS at $28{ }^{\circ} \mathrm{C}$ are presented in Figure 3. Five identical samples were used for each test case and the detailed results of each sample are available in Figure S2. The resistance curves increased immediately after starting the soaking test, indicating that corrosion occurred immediately. After two to four days, the lifetime criterion of $3 R_{0}$ was reached, and corrosion at the $\mathrm{Cu}$ meanders was clearly visible. The average lifetime of meanders showed a positive correlation to its width (2.7 days for a width of $30 \mu \mathrm{m}$ versus 3.4 and 3.5 days for a width of 40 and $50 \mu \mathrm{m}$, respectively). Probably, these differences were observed because the amount of $\mathrm{Cu}$ on the $50 \mu \mathrm{m}$ meander to be corroded was larger than the meanders with a width of 40 and $30 \mu \mathrm{m}$. All resistance measurements of the bare Cu meanders $(40 \mu \mathrm{m})$ against soaking time at various temperatures are presented in Figure S3, and the detailed data are shown in Table S1.

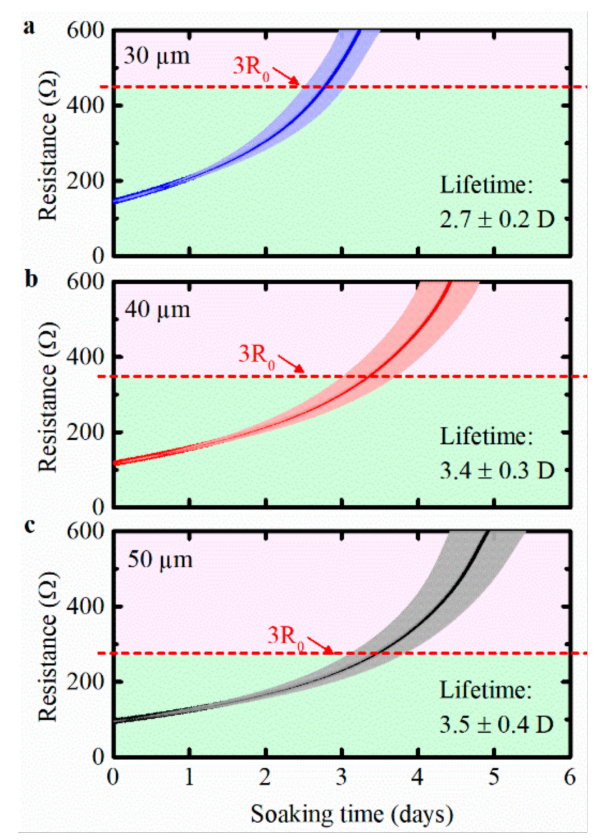

Figure 3. Bare $\mathrm{Cu}$ meander samples with different width soaked in phosphate buffered saline (PBS) at $28^{\circ} \mathrm{C}$ : (a) $30 \mu \mathrm{m}$; (b) $40 \mu \mathrm{m}$; (c) $50 \mu \mathrm{m}$. Each test used five identical samples, the shaded area is \pm standard deviation. 
To evaluate the corrosion of bare $\mathrm{Cu}$ meanders at elevated temperature, the meanders were soaked in PBS at different temperatures, ranging from $21^{\circ} \mathrm{C}$ to $95^{\circ} \mathrm{C}$. The lifetimes of the bare $\mathrm{Cu}$ meanders with a width of $40 \mu \mathrm{m}$ soaked at various temperatures are shown in Figure $4 \mathrm{a}$. In the range of $21-75^{\circ} \mathrm{C}$, the lifetime decreased exponentially with the soaking temperature. Above $80^{\circ} \mathrm{C}$, further increase in the soaking temperature resulted in an increased lifetime. This suggests that corrosion was slowed down for the bare $\mathrm{Cu}$ meanders. At these temperatures, the failure mechanism changed. A possible explanation for the reduction in corrosion rate at temperatures above $75^{\circ} \mathrm{C}$ is the reduced concentration of dissolved oxygen in PBS at those temperatures. It is known that the amount of dissolved oxygen will decrease significantly when the temperature of the water increases $[45,46]$. Therefore, the oxidation reaction will first speed up when the test temperature increases, until the temperature is reached at which the limited presence of oxygen will significantly decrease the speed of oxidation.
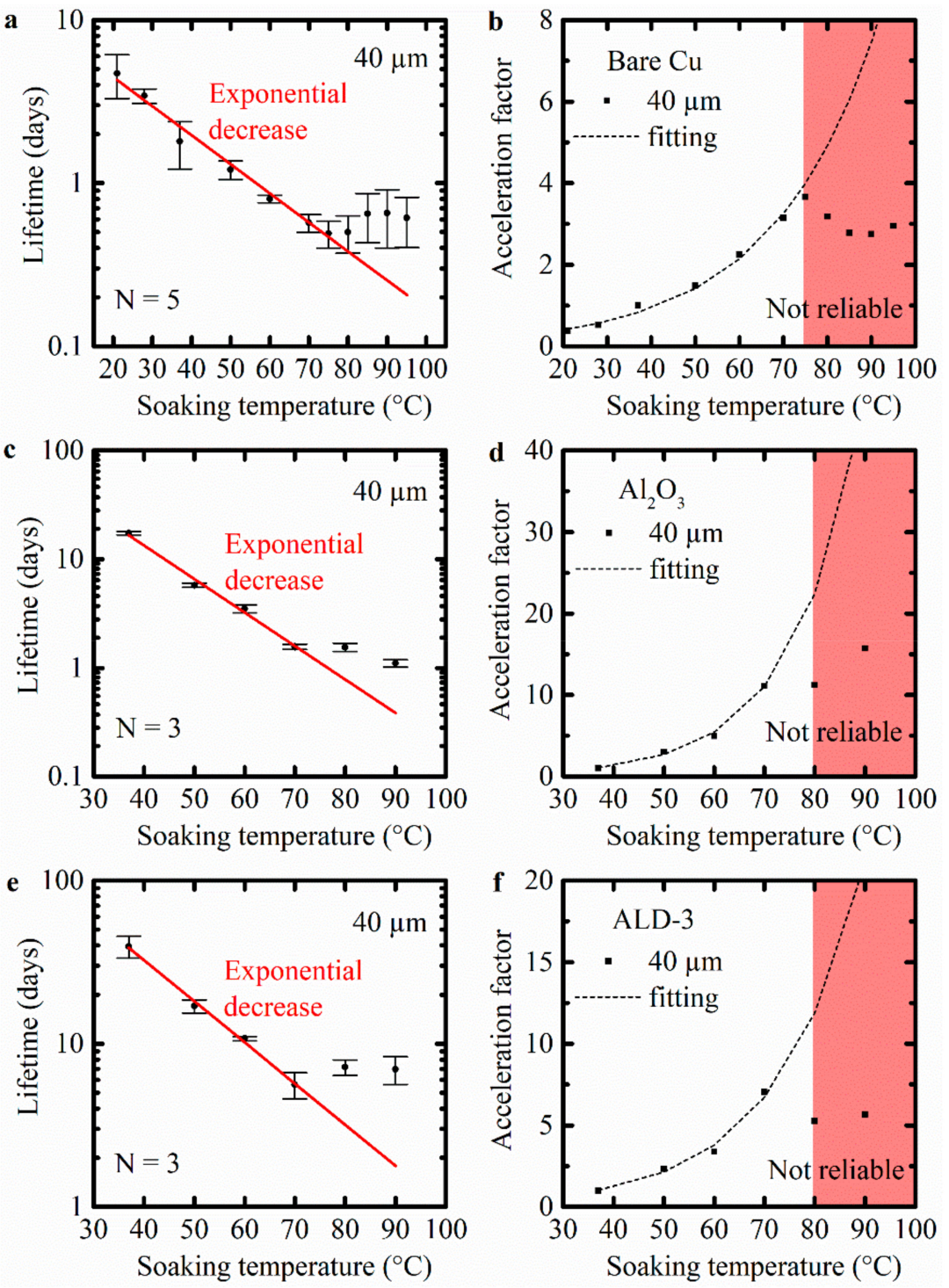

Figure 4. The lifetime and the acceleration factors against the soaking temperature $\left({ }^{\circ} \mathrm{C}\right)$ of $\mathrm{Cu}$ meanders (width of $40 \mu \mathrm{m})$ soaked in PBS at various temperatures: $(\mathbf{a}-\mathbf{b})$ uncoated $\mathrm{Cu}$ meanders $(\mathrm{N}=5)$; (c-d) $\mathrm{ALD} \mathrm{Al}_{2} \mathrm{O}_{3}$ protected $\mathrm{Cu}$ meanders $(\mathrm{N}=3)$; $(\mathbf{e}-\mathbf{f})$ ALD-3 protected $\mathrm{Cu}$ meanders $(\mathrm{N}=3)$. " $\mathrm{N}$ " is the number of tested samples, and the bars show standard deviation.

The acceleration factor at elevated temperatures was calculated and plotted in Figure $4 \mathrm{~b}$. For the accelerated corrosion test of bare $\mathrm{Cu}$ meanders, the lifetime decreased with a factor of 1.5 per $10^{\circ} \mathrm{C}$ 
increase in test temperature, up to $75^{\circ} \mathrm{C}$. However, for temperatures above $75^{\circ} \mathrm{C}$, accelerated testing was not reliable anymore.

\subsection{Evaluation of the Performance of Protected $\mathrm{Cu}$ Meanders: $A L D A l_{2} \mathrm{O}_{3}$ and $A L D-3$ as Barrier Layers}

$\mathrm{Cu}$ meander samples coated with $\mathrm{ALD} \mathrm{Al}_{2} \mathrm{O}_{3}$ and ALD-3 were exposed to PBS at temperatures ranging from $37^{\circ} \mathrm{C}$ to $90^{\circ} \mathrm{C}$, and subjected to the same test method for uncoated meanders.

The lifetime of the $\mathrm{Al}_{2} \mathrm{O}_{3}$ coated meanders with a width of $40 \mu \mathrm{m}$ soaked at various temperatures is shown in Figure 4c. Individual resistance measurements for each sample of the $\mathrm{Cu}$ meanders against soaking time at various temperatures are provided in Figure S4 and the detailed data are shown in Table S1. Due to the presence of the ALD barrier, the resistance of the meanders remained stable for a certain time (depending on the soaking temperature) before increasing rapidly. This stable resistance indicated that the $\mathrm{Al}_{2} \mathrm{O}_{3}$ barrier protected the underlying $\mathrm{Cu}$ meanders during these specific soaking periods. As the hydrolysis of $\mathrm{Al}_{2} \mathrm{O}_{3}$ progressed, the barrier started to fail. The $\mathrm{Cu}$ meanders were exposed to the PBS and started to corrode. In the temperature range from $37^{\circ} \mathrm{C}$ to $70{ }^{\circ} \mathrm{C}$, the lifetime decreased exponentially with the soaking temperature. The lifetime of the meanders decreased more slowly at temperatures of $80^{\circ} \mathrm{C}$ and $90^{\circ} \mathrm{C}$, since the reduced concentration of oxygen in PBS slowed down the corrosion of the $\mathrm{Cu}$. The contribution of the $\mathrm{Cu}$ corrosion to the overall lifetime outweighed the barrier degradation at higher temperatures. Take the lifetimes at $70^{\circ} \mathrm{C}$ and $90^{\circ} \mathrm{C}$ as examples. The lifetimes of bare $\mathrm{Cu}$ meanders were 0.57 days $\left(70^{\circ} \mathrm{C}\right)$ and 0.66 days $\left(90^{\circ} \mathrm{C}\right)$, while the same values for $\mathrm{Al}_{2} \mathrm{O}_{3}$-coated $\mathrm{Cu}$ meanders were 1.57 days $\left(70^{\circ} \mathrm{C}\right)$ and 1.01 days $\left(90^{\circ} \mathrm{C}\right)$. The lifetime extension of bare $\mathrm{Cu}$ meanders protected by $\mathrm{Al}_{2} \mathrm{O}_{3}$ was $1.00\left(70{ }^{\circ} \mathrm{C}\right)$ and 0.35 days $\left(90^{\circ} \mathrm{C}\right)$. This revealed that hydrolysis of $\mathrm{Al}_{2} \mathrm{O}_{3}$ was still accelerated at higher temperatures. Also, for this barrier material, the lifetime prediction by means of the Arrhenius equation was not reliable at high temperatures. In conclusion, for the accelerated tests with $\mathrm{Al}_{2} \mathrm{O}_{3}$, the lifetime decreased with a factor of 2.0 per $10^{\circ} \mathrm{C}$ increase in test temperature, up to $70{ }^{\circ} \mathrm{C}$ (Figure $4 \mathrm{~d}$ ).

The results for the ALD-3 coated meander soaked at various temperatures are shown in Figure 4e. In Figure S5, all individual resistance measurements of the meanders protected by ALD-3 against soaking time at the different temperatures are shown. The corresponding detailed data are provided in Table S1. For ALD-3 barrier, there was a higher variation in the measured lifetime from sample to sample. This was partially related to the longer soaking time, although the dominant factor was the different degradation process in this case (see Section 3.3). The decrease in the lifetime followed an Arrhenius behavior until $70^{\circ} \mathrm{C}$. At temperatures above $80^{\circ} \mathrm{C}$, the lifetime prediction no longer followed the Arrhenius equation. Figure $4 \mathrm{f}$ shows the acceleration factor for accelerated testing in the case of protection by the ALD-3 barrier. For the ALD-3 barrier, the lifetime decreased with a factor of 1.8 per $10{ }^{\circ} \mathrm{C}$ increase in test temperature. This was valid for temperatures up to $70^{\circ} \mathrm{C}$.

The equivalent soaking time for $70{ }^{\circ} \mathrm{C}$ relative to $37^{\circ} \mathrm{C}$ was calculated based on the acceleration factors for the three test cases, shown in Table 1.

In conclusion, the lifetime in days $\left(37^{\circ} \mathrm{C}-70^{\circ} \mathrm{C}\right)$ increased in the following order: uncoated $\mathrm{Cu}$ meanders $<\mathrm{ALD} \mathrm{Al}_{2} \mathrm{O}_{3}<\mathrm{ALD}-3$. Limitations in the temperature used for accelerated testing were observed for all barrier materials.

Table 1. Equivalent soaking time and acceleration factors for $70{ }^{\circ} \mathrm{C}$ relative to $37{ }^{\circ} \mathrm{C}$ for the three test cases.

\begin{tabular}{cccc}
\hline $\begin{array}{c}\text { Barrier Layer on } \\
\mathbf{C u} \text { Meanders }\end{array}$ & $\begin{array}{c}\text { Soaking Time at } \\
\mathbf{7 0}{ }^{\circ} \mathbf{C} \text { (Day) }\end{array}$ & $\begin{array}{c}\text { Equivalent Soaking } \\
\text { Time at } \mathbf{3}{ }^{\circ} \mathbf{C} \text { (Day) }\end{array}$ & Acceleration Factor \\
\hline None & 0.57 & 2.17 & 3.8 \\
$\mathrm{Al}_{2} \mathrm{O}_{3}$ & 1.57 & 15.46 & 9.8 \\
$\mathrm{ALD}-3$ & 5.61 & 39.02 & 7.0 \\
\hline
\end{tabular}




\subsection{Corrosion Failure of Meanders for Three Test Cases: Uncoated Cu Meanders, $A L D A l_{2} \mathrm{O}_{3}$, and $A L D-3$}

The results of the electrical resistance measurements when immersing the meanders in PBS at $60{ }^{\circ} \mathrm{C}$ are shown in Figure 5a. The uncoated $\mathrm{Cu}$ meanders showed fast and steady corrosion, as expected. When the meanders were protected by $\mathrm{Al}_{2} \mathrm{O}_{3}$, the $\mathrm{Cu}$ corrosion was delayed. After a few days in the fluid, the $\mathrm{Al}_{2} \mathrm{O}_{3}$ was fully hydrolyzed, and the barrier function disappeared completely. At that point, corrosion of the $\mathrm{Cu}$ meanders occurred quickly, which resulted in a steep increase in resistance.
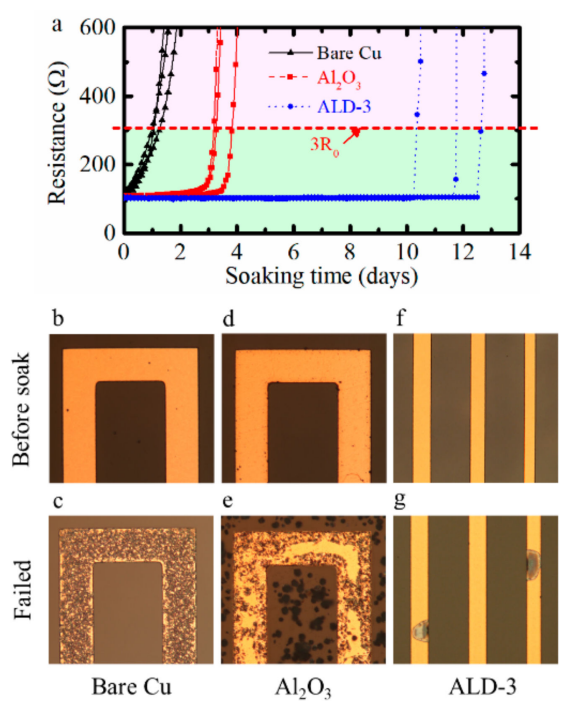

Figure 5. Corrosion of $\mathrm{Cu}$ meanders for three test cases soaked at $60{ }^{\circ} \mathrm{C}$ : (a) resistance change of meanders against soaking time in PBS; (b) bare $\mathrm{Cu}$ meanders before soak; (c) bare $\mathrm{Cu}$ meanders soaked for one day and failed; (d) $\mathrm{Cu}$ meanders with $\mathrm{Al}_{2} \mathrm{O}_{3}$ barrier before soak; (e) Cu meanders with $\mathrm{Al}_{2} \mathrm{O}_{3}$ barrier soaked for 3.3 days and failed; (f) Cu meanders with ALD-3 barrier before soak; (g) Cu meanders with ALD-3 barrier soaked for 13 days and failed.

In the case where the $\mathrm{Cu}$ meanders were protected with ALD-3, the resistance remained stable for a much longer time. After about 10 to 13 days, the resistivity increased dramatically. The ALD-3 layer protected the meanders for a longer time, but also the degradation process was different, indicating that the overall failure mechanism changed.

To understand the shape of the resistance curve versus soaking time, the corrosion failure process for the three configurations was studied. In the case of bare $\mathrm{Cu}$ meanders, corrosion started fast and uniformly across the samples, as shown in Figure $5 \mathrm{~b}$,c. $\mathrm{Cu}$ corrosion on the samples protected by $\mathrm{Al}_{2} \mathrm{O}_{3}$ occurred rather uniformly, as shown in Figure 5d,e. Based on this observation, it was assumed that the hydrolysis of the $\mathrm{Al}_{2} \mathrm{O}_{3}$ layer is a uniform process. There was a small tendency to have faster corrosion at edges of the $\mathrm{Cu}$ patterns, probably because the $\mathrm{ALD} \mathrm{Al}_{2} \mathrm{O}_{3}$ layer was slightly thinner at the edges.

In the case where the ALD-3 barrier was used for protection, the corrosion started at only a few spots. The corroded spot grew until its size matched the width of the meander. This resulted in a steep increase in the resistance of the meander, i.e., sample failure. The onset of the corrosion was typically at the side of the $\mathrm{Cu}$ tracks and there was no indication at all of any global degradation of the ALD-3 layer, as shown in Figure 5f,g. SEM inspection after corrosion testing revealed a crack at the edge of the $\mathrm{Cu}$ track (see Figure 6). Before corrosion testing, these cracks were not visible, but small cracks might have been present already. The ALD-3 layer was very thin and conformal, and hence very difficult to observe on top of the $\mathrm{Cu}$ pattern. It was difficult to obtain straight forward proof. Possibly, this is related to the thermal expansion/shrinkage during the ALD deposition, which happened at $250^{\circ} \mathrm{C}$. Differences in the coefficient of thermal expansion (CTE) between glass (3.25 ppm/K) $[47,48]$, $\mathrm{Cu}(17 \mathrm{ppm} / \mathrm{K})$ [49], and the ALD materials (5-7 ppm /K) [50] might generate small cracks in the ALD layer due to stress concentration at the $\mathrm{Cu}$ edges, and hence local degradation can happen rather fast. 


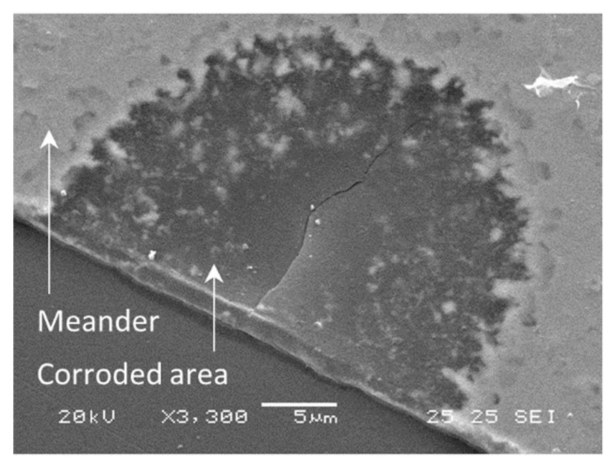

Figure 6. SEM picture of a corrosion spot on an ALD-3-protected Cu meander. The crack started at the side of the meander and grew as the $\mathrm{Cu}$ below was dissolved.

\subsection{PI Combined with ALD-3 to Protect $C u$ Meanders}

A PI layer of $5 \mu \mathrm{m}$ was spin coated on the Cu meanders. The layer thickness of the PI was much larger compared to the ALD barrier layers discussed in Sections 3.2 and 3.3. As a consequence, the layers containing PI are discussed separately. Spin-coated PI layers combined with ALD stacks are interesting for the development of flexible implantable devices, as discussed in reference [12]. The WVTR of PI decreased significantly by sandwiching the ALD-3 between two PI layers, from $4300 \mathrm{mg} /\left(\mathrm{cm}^{2} \cdot\right.$ day $)$ to a value below the detection limit of the WVTR tool $\left(0.5 \mathrm{mg} /\left(\mathrm{cm}^{2} \cdot\right.\right.$ day $)$ [4]. The major disadvantage of this type of spin-coat PI is that conformal coating of 3D devices is not possible.

On the samples with only PI, the three tested samples failed after roughly one year soaked in PBS at $60^{\circ} \mathrm{C}$ in the oven. The steep increases in the resistance indicated that failure of the meanders happened in a short period, as shown in Figure 7a. Figure $7 \mathrm{~b}$ shows a typical failure of meanders. We hypothesize that moisture diffuses through the local defects on PI layer and condenses on locations at the interface where adhesion is not perfect. Blisters are formed in these locations and $\mathrm{Cu}$ corrosion is observed. It is important to mention that the failure spots or areas of PI coating layer are local rather than global.
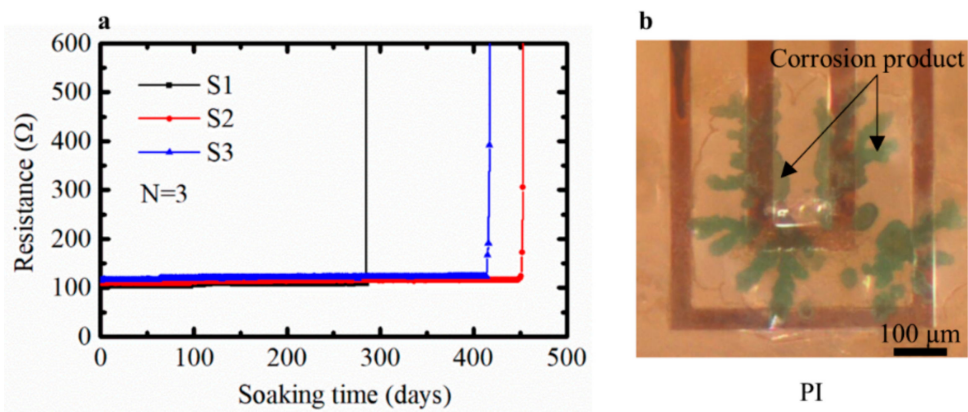

PI

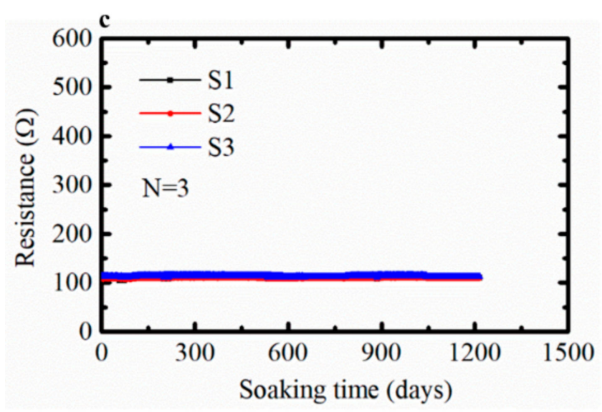

Figure 7. Resistance against soaking time of $\mathrm{Cu}$ meanders protected by (a) PI and (b) its failure meanders; (c) PI/ALD-3/PI and (d) meanders under perfect protection by the PI/ALD-3/PI. S1, S2, and S3 indicate the three samples for each test. 
The $\mathrm{Cu}$ meanders protected by the PI/ALD-3/PI film were immersed in PBS at $60^{\circ} \mathrm{C}$. The resistance of meanders remained stable over the 1215 days of soaking period at $60^{\circ} \mathrm{C}$ (Figure 7c), which indicated the absence of corrosion on the $\mathrm{Cu}$ meanders. Moreover, no visible degradation phenomena were observed during inspection with the optical microscope. Figure $7 \mathrm{~d}$ shows a typical image of the PI/ALD-3/PI-protected Cu meanders. Based on this result it can be concluded that the ultrathin ALD-3 barrier can stop the penetration of PBS into the encapsulation layer effectively for at least 1215 days with good coverage on the protected meanders surface.

\section{Conclusions}

Accelerated testing was studied for several test cases using ALD layers as a moisture barrier to protect $\mathrm{Cu}$ meanders from corrosion during soaking in PBS at temperatures between $21^{\circ} \mathrm{C}$ and $95^{\circ} \mathrm{C}$. The Arrhenius relationship between lifetime measured by meander resistance test and soaking temperature was valid at a temperature lower than $70^{\circ} \mathrm{C}$ for uncoated $\mathrm{Cu}$ and $\mathrm{Cu}$ protected by ALD $\mathrm{Al}_{2} \mathrm{O}_{3}$ and ALD-3. The acceleration protocol enabled the estimation of the lifetime at $37^{\circ} \mathrm{C}$, while avoiding a time-consuming real-conditions durability test. The lifetime decreased by a factor of 1.5 , 2.0, and 1.8 per $10^{\circ} \mathrm{C}$ increase in test temperature for bare, $\mathrm{ALD} \mathrm{Al}_{2} \mathrm{O}_{3}$, and ALD-3 Cu meanders, respectively. The lifetime of 1.0 day at $70{ }^{\circ} \mathrm{C}$ equaled $3.8,9.8$, and 7.0 days at reference temperature $37^{\circ} \mathrm{C}$ for the three test cases. Accelerating oxygen dependent processes, like $\mathrm{Cu}$ corrosion, in saline solutions by increasing the test temperature has inherent limitations. Each material combination resulted in a different acceleration factor, confirming that the acceleration factor is valid only for a dedicated test situation.

For various moisture barriers applied on top of $\mathrm{Cu}$ meanders, different corrosion locations/patterns were observed during or after sample testing. The bare $\mathrm{Cu}$ corrosion in PBS started fast and was present uniformly over the sample. The corrosion of $\mathrm{Cu}$ protected by $\mathrm{ALD} \mathrm{Al}_{2} \mathrm{O}_{3}$ showed a tendency to be faster at all edges of the $\mathrm{Cu}$ structures. In the case of ALD-3-protected $\mathrm{Cu}$ meanders, the corrosion only happened on a few isolated spots located at the edges of the $\mathrm{Cu}$ lines. The $\mathrm{Cu}$ traces coated with PI corroded as water diffused through the PI layer to the interface, where bad adhesion presented.

PI/ALD-3/PI barriers on Cu meanders did not degrade after more than 1215 days soaking in PBS at $60^{\circ} \mathrm{C}$. An encapsulation solution was applied to an active high-density transverse intrafascicular micro-electrode probe to interface with the peripheral nervous system based on the stack of PI and ALD-3 technology [40]. Therefore, we conclude that the PI/ALD-3/PI barrier shows great potential to act as a moisture barrier for the encapsulation of implantable medical devices.

Supplementary Materials: The following are available online at http://www.mdpi.com/2079-6412/10/1/19/ s1-Figure S1: The lifetime definition is based on the resistance test. The green background area indicates that the $\mathrm{Cu}$ meanders are still intact, while the red background zone means that the $\mathrm{Cu}$ meander has failed; Figure S2: Bare Cu meander samples with different widths soaked in PBS at $28^{\circ} \mathrm{C}$ : a. $30 \mu \mathrm{m}, \mathrm{b} .40 \mu \mathrm{m}, \mathrm{c} .50 \mu \mathrm{m}$. Each curve indicates one sample, each test has five identical samples; Figure S3: Lifetime of bare Cu meanders soaking in PBS up to $95^{\circ} \mathrm{C}$. Each curve indicates an independent sample; Figure S4: Lifetime of $20 \mathrm{~nm}$ ALD $\mathrm{Al}_{2} \mathrm{O}_{3}$-protected $\mathrm{Cu}$ meanders soaking in PBS up to $90^{\circ} \mathrm{C}$. Each curve indicates an independent sample; Figure S5: Lifetime of ALD $8 \mathrm{~nm} \mathrm{HfO} 2 / 20 \mathrm{~nm} \mathrm{Al} \mathrm{O}_{3} / 8 \mathrm{~nm} \mathrm{HfO} \mathrm{H}_{2}$-protected Cu meanders soaking in PBS up to $90{ }^{\circ} \mathrm{C}$. Each curve indicates an independent sample; Table S1: Average lifetime (days) of Cu meanders soaking in PBS.

Author Contributions: Experiments, C.L. and L.M.; analysis, C.L. and M.C.; writing-original draft preparation, C.L.; writing-review and editing, D.S., M.C., and M.O.d.B. All authors have read and agreed to the published version of the manuscript.

Funding: This work was partly supported by the China Scholarship Council (201406150084).

Acknowledgments: We thank Filip Vermeiren, Kristof Dhaenens, Sheila Dunphy, Filip Thielemans for samples preparation. We thank Yang Yang for the effort on revising this paper.

Conflicts of Interest: The authors declare no conflict of interest. 


\section{Nomenclature}

$\begin{array}{ll}\text { ALD } & \text { atomic layer deposition } \\ \text { ALD-3 } & \mathrm{HfO}_{2} / \mathrm{Al}_{2} \mathrm{O}_{3} / \mathrm{HfO}_{2} \\ \text { FBR } & \text { foreign body reaction } \\ \text { PDMS } & \text { polydimethylsiloxane } \\ \text { WVTR } & \text { water vapor transmission rate } \\ \text { OLED } & \text { organic light-emitting diode } \\ \text { PI } & \text { Polyimide } \\ \text { BPDA-PPD } & \text { biphenyltetracarboxylic dianhydride and paraphenylenediamine } \\ \text { RH } & \text { relative humidity } \\ \text { EIS } & \text { electrochemical impedance spectroscopy } \\ \text { FIB-SEM } & \text { focused ion beam scanning electron microscopes } \\ \text { PBS } & \text { phosphate buffered saline } \\ \text { CTE } & \text { coefficient of thermal expansion. }\end{array}$

\section{References}

1. Lacour, S.P.; Courtine, G.; Guck, J. Materials and technologies for soft implantable neuroprostheses. Nat. Rev. Mater. 2016, 1, 1-14. [CrossRef]

2. Xue, Y.; Shiuan, Y.; McIlvried, L.A.; Copits, B.A.; Noh, K.N.; Zhang, J.; Samineni, V.K.; Payne, M.A.; Won, S.M.; Kim, B.H.; et al. A wireless closed-loop system for optogenetic peripheral neuromodulation. Nature 2018, 565, 361-365.

3. Jiang, G.; Zhou, D.D. Implantable Neural Prostheses; Springer: New York, NY, USA, 2010; ISBN 978-0-387-98119-2.

4. De Op Beeck, M.; Verplancke, R.; Schaubroeck, D.; Cuypers, D.; Cauwe, M. Ultra-thin biocompatible implantable chip for bidirectional communication with peripheral nerves. In Proceedings of the 2017 IEEE Biomedical Circuits and Systems Conference, Turin, Italy, 19-21 October 2017; pp. 1-4.

5. Liu, Y.; Liu, J.; Chen, S.; Lei, T.; Kim, Y.; Niu, S.; Wang, H.; Wang, X.; Foudeh, A.M.; Tok, J.B.H.; et al. Soft and elastic hydrogel-based microelectronics for localized low-voltage neuromodulation. Nat. Biomed. Eng. 2019, 3, 58-68. [CrossRef] [PubMed]

6. Scholten, K.; Meng, E. Materials for microfabricated implantable devices: A review. Lab Chip 2015, 15, 4256-4272. [CrossRef]

7. Schaubroeck, D.; Verplancke, R.; Cauwe, M.; Cuypers, D.; Baumans, K.; Op De Beeck, M. Polyimide-ALD-polyimide layers as hermetic encapsulant for implants. In Proceedings of the XXXI International Conference on Surface Modification Technologies (SMT31), Mons, Belgium, 5-7 July 2017; pp. 1-6.

8. Zhang, B.; Li, W.; Yang, Y.; Chen, C.; Li, C.-F.; Suganuma, K. Fully embedded CuNWs/PDMS conductor with high oxidation resistance and high conductivity for stretchable electronics. J. Mater. Sci. 2019, 54, 6381-6392. [CrossRef]

9. Xie, X.; Rieth, L.; Caldwell, R.; Diwekar, M.; Tathireddy, P.; Sharma, R.; Solzbacher, F. Long-term bilayer encapsulation performance of atomic layer deposited $\mathrm{Al}_{2} \mathrm{O}_{3}$ and parylene $\mathrm{C}$ for biomedical implantable devices. IEEE Trans. Biomed. Eng. 2013, 60, 2943-2951.

10. Yang, Y.; Martens, T.; Vandecasteele, B.; Degrendele, L.; Mader, L.; De Vriese, L.; Sekitani, T.; Kaufmann, M.; Van Put, S.; Vervust, T.; et al. 3D Multifunctional Composites Based on Large-Area Stretchable Circuit with Thermoforming Technology. Adv. Electron. Mater. 2018, 4, 1800071. [CrossRef]

11. Teo, A.J.T.; Mishra, A.; Park, I.; Kim, Y.J.; Park, W.T.; Yoon, Y.J. Polymeric Biomaterials for Medical Implants and Devices. ACS Biomater. Sci. Eng. 2016, 2, 454-472. [CrossRef]

12. Kim, S.H.; Moon, J.H.; Kim, J.H.; Jeong, S.M.; Lee, S.H. Flexible, stretchable and implantable PDMS encapsulated cable for implantable medical device. Biomed. Eng. Lett. 2011, 1, 199-203. [CrossRef]

13. Lecomte, A.; Degache, A.; Descamps, E.; Dahan, L.; Bergaud, C. In vitro and in vivo biostability assessment of chronically-implanted Parylene C neural sensors. Sens. Actuators B Chem. 2017, 251, 1001-1008. [CrossRef]

14. Ahn, S.-H.; Jeong, J.; Kim, S.J. Emerging Encapsulation Technologies for Long-Term Reliability of Microfabricated Implantable Devices. Micromachines 2019, 10, 508. [CrossRef] [PubMed] 
15. George, S.M. George Atomic Layer Deposition: An Overview. Chem. Rev. 2010, 110, 111. [CrossRef]

16. Wang, H.; Liu, Y.; Liu, H.; Chen, Z.; Xiong, P.; Xu, X.; Chen, F.; Li, K.; Duan, Y. Effect of Various Oxidants on Reaction Mechanisms, Self-Limiting Natures and Structural Characteristics of $\mathrm{Al}_{2} \mathrm{O}_{3}$ Films Grown by Atomic Layer Deposition. Adv. Mater. Interfaces 2018, 5, 1-7. [CrossRef]

17. Noked, M.; Rubloff, G.W.; Lin, C.-F.; Kozen, A.C.; Liu, C. ALD Protection of Li-Metal Anode Surfaces-Quantifying and Preventing Chemical and Electrochemical Corrosion in Organic Solvent. Adv. Mater. Interfaces 2016, 3, 1600426.

18. Vanhaverbeke, C.; Cauwe, M.; Stockman, A.; Op de Beeck, M.; De Smet, H. Comparison of copper electroplating, copper wet etching and linear sweep voltammetry as techniques to investigate the porosity of atomic layer deposited $\mathrm{Al}_{2} \mathrm{O}_{3}$. Thin Solid Film. 2019, 686, 137424. [CrossRef]

19. Iacob, N.; Chindriş, I. Low-temperature atomic layer deposition of $\mathrm{Al}_{2} \mathrm{O}_{3}$ thin coatings for corrosion protection of steel: Surface and electrochemical analysis. Corros. Sci. 2012, 53, 2168-2175.

20. Yoon, K.H.; Kim, H.S.; Han, K.S.; Kim, S.H.; Lee, Y.E.K.; Shrestha, N.K.; Song, S.Y.; Sung, M.M. Extremely High Barrier Performance of Organic-Inorganic Nanolaminated Thin Films for Organic Light-Emitting Diodes. ACS Appl. Mater. Interfaces 2017, 9, 5399-5408. [CrossRef]

21. Klumbies, H.; Schmidt, P.; Hähnel, M.; Singh, A.; Schroeder, U.; Richter, C.; Mikolajick, T.; Hoßbach, C.; Albert, M.; Bartha, J.W.; et al. Thickness dependent barrier performance of permeation barriers made from atomic layer deposited alumina for organic devices. Org. Electron. 2015, 17, 138-143. [CrossRef]

22. Graff, G.L.; Williford, R.E.; Burrows, P.E. Mechanisms of vapor permeation through multilayer barrier films: Lag time versus equilibrium permeation. J. Appl. Phys. 2004, 96, 1840-1849. [CrossRef]

23. Abdulagatov, A.I.; Yan, Y.; Cooper, J.R.; Zhang, Y.; Gibbs, Z.M.; Cavanagh, A.S.; Yang, R.G.; Lee, Y.C.; George, S.M. $\mathrm{Al}_{2} \mathrm{O}_{3}$ and $\mathrm{TiO}_{2}$ atomic layer deposition on copper for water corrosion resistance. ACS Appl. Mater. Interfaces 2011, 3, 4593-4601. [CrossRef]

24. Kim, L.H.; Jang, J.H.; Jeong, Y.J.; Kim, K.; Baek, Y.; Kwon, H.-j.; An, T.K.; Nam, S.; Kim, S.H.; Jang, J.; et al. Highly-impermeable $\mathrm{Al}_{2} \mathrm{O}_{3} / \mathrm{HfO}_{2}$ moisture barrier films grown by low-temperature plasma-enhanced atomic layer deposition. Org. Electron. 2017, 50, 296-303. [CrossRef]

25. Daubert, J.S.; Hill, G.T.; Gotsch, H.N.; Gremaud, A.P.; Ovental, J.S.; Williams, P.S.; Oldham, C.J.; Parsons, G.N. Corrosion protection of copper using $\mathrm{Al}_{2} \mathrm{O}_{3}, \mathrm{TiO}_{2}, \mathrm{ZnO}, \mathrm{HfO}_{2}$, and $\mathrm{ZrO}_{2}$ Atomic layer deposition. ACS Appl. Mater. Interfaces 2017, 9, 4192-4201. [CrossRef] [PubMed]

26. Dameron, A.A.; Davidson, S.D.; Burton, B.B.; Carcia, P.F.; Scott McLean, R.; George, S.M. Gas diffusion barriers on polymers using multilayers fabricated by $\mathrm{Al}_{2} \mathrm{O}_{3}$ and rapid $\mathrm{SiO}_{2}$ atomic layer deposition. J. Phys. Chem. C 2008, 112, 4573-4580. [CrossRef]

27. Zhang, Y.; Bertrand, J.A.; Yang, R.; George, S.M.; Lee, Y.C. Electroplating to visualize defects in $\mathrm{Al}_{2} \mathrm{O}_{3}$ thin films grown using atomic layer deposition. Thin Solid Films 2009, 517, 3269-3272. [CrossRef]

28. Loveday, D.; Peterson, P.; Rodgers, B. Evaluation of Organic Coatings with Electrochemical Impedance Spectroscopy Part 2: Application of EIS to Coatings. JCT Coat. Technol. 2004, 10, 88-93.

29. Li, C.; Cauwe, M.; Yang, Y.; Schaubroeck, D.; Mader, L. Ultra-Long-Term Reliable Encapsulation Using an Atomic Layer Deposited $\mathrm{HfO}_{2} / \mathrm{Al}_{2} \mathrm{O}_{3} / \mathrm{HfO}_{2}$ Triple-Interlayer for Biomedical Implants. Coatings 2019, 9, 579. [CrossRef]

30. Nelson, W.B. Accelerated Testing: Statistical Models, Test Plans, and Data Analysis; Wiley: Hoboken, NJ, USA, 2009; ISBN 0471697362.

31. Hukins, D.W.L.; Mahomed, A.; Kukureka, S.N. Accelerated aging for testing polymeric biomaterials and medical devices. Med. Eng. Phys. 2008, 30, 1270-1274. [CrossRef]

32. Hemmerich, K.J. Hemmerich General aging theory and simplified protocol for accelerated aging of medical devices. Med. Plast. Biomater. 1998, 5, 16-23.

33. Minnikanti, S.; Diao, G.; Pancrazio, J.J.; Xie, X.; Rieth, L.; Solzbacher, F.; Peixoto, N. Lifetime assessment of atomic-layer-deposited $\mathrm{Al}_{2} \mathrm{O}_{3}$-Parylene $\mathrm{C}$ bilayer coating for neural interfaces using accelerated age testing and electrochemical characterization. Acta Biomater. 2014, 10, 960-967. [CrossRef]

34. Meyer, J.-U.; Stieglitz, T.; Scholz, O.; Haberer, W.; Beutel, H. High Density Interconnects and Flexible Hybrid Assemblies for Active Biomedical Implants. IEEE Trans. Adv. Packag. 2001, 24, 366-374. [CrossRef]

35. Yang, Y.; Xu, K.; Vervust, T.; Vanfleteren, J. Multifunctional and miniaturized flexible sensor patch: Design and application for in situ monitoring of epoxy polymerization. Sens. Actuators B Chem. 2018, 261, 144-152. [CrossRef] 
36. Yang, Y.; Chiesura, G.; Plovie, B.; Vervust, T.; Luyckx, G.; Degrieck, J.; Sekitani, T.; Vanfleteren, J. Design and Integration of Flexible Sensor Matrix for in Situ Monitoring of Polymer Composites. ACS Sens. 2018, 3 , 1698-1705. [CrossRef] [PubMed]

37. Sun, Y.; Lacour, S.P.; Brooks, R.A.; Rushton, N.; Fawcett, J.; Cameron, R.E. Assessment of the biocompatibility of photosensitive polyimide for implantable medical device use. J. Biomed. Mater. Res. Part A 2009, 90, 648-655. [CrossRef] [PubMed]

38. Hassler, C.; Boretius, T.; Stieglitz, T. Polymers for neural implants. J. Polym. Sci. Part B Polym. Phys. 2011, 49, 18-33. [CrossRef]

39. Herth, E.; Guerchouche, K.; Rousseau, L.; Calvet, L.E.; Loyez, C. A biocompatible and flexible polyimide for wireless sensors. Microsyst. Technol. 2017, 23, 5921-5929. [CrossRef]

40. Verplancke, R.; Cauwe, M.; Schaubroeck, D.; Cuypers, D.; Ballini, M.; Callaghan, J.O.; Goikoetxea, E.; Braeken, D.; Bashirullah, R.; Op de Beeck, M. Development of an active high-density transverse intrafascicular micro-electrode probe. J. Micromech. Microeng. 2020, 30, 015010. [CrossRef]

41. Xie, X.; Rieth, L.; Williams, L.; Negi, S.; Bhandari, R.; Caldwell, R.; Sharma, R.; Tathireddy, P.; Solzbacher, F. Long-term reliability of $\mathrm{Al}_{2} \mathrm{O}_{3}$ and Parylene $\mathrm{C}$ bilayer encapsulated Utah electrode array based neural interfaces for chronic implantation. J. Neural Eng. 2014, 11, 026016. [CrossRef]

42. Field, J.A.; Luna-Velasco, A.; Boitano, S.A.; Shadman, F.; Ratner, B.D.; Barnes, C.; Sierra-Alvarez, R. Cytotoxicity and physicochemical properties of hafnium oxide nanoparticles. Chemosphere 2011, 84, 1401-1407. [CrossRef]

43. Finch, D.S.; Oreskovic, T.; Ramadurai, K.; Herrmann, C.F.; George, S.M.; Mahajan, R.L. Biocompatibility of atomic layer-deposited alumina thin films. J. Biomed. Mater. Res. Part A 2008, 87, 100-106. [CrossRef]

44. Jeong, J.; Laiwalla, F.; Lee, J.; Ritasalo, R.; Pudas, M.; Larson, L.; Leung, V.; Nurmikko, A. Conformal Hermetic Sealing of Wireless Microelectronic Implantable Chiplets by Multilayered Atomic Layer Deposition (ALD). Adv. Funct. Mater. 2019, 29, 1-10. [CrossRef]

45. Benson, B.B.; Krause, D.; Peterson, M.A. The solubility and isotopic fractionation of gases in dilute aqueous solution. I. Oxygen. J. Solut. Chem. 1979, 8, 665-690. [CrossRef]

46. Tromans, D. Modeling Oxygen Solubility in Water and Electrolyte Solutions. Ind. Eng. Chem. Res. 2000, 39, 805-812. [CrossRef]

47. Schott BOROFLOATß33-Thermal Properties. Available online: https:/www.schott.com/d/borofloat/ b89578c1-3509-40a2-aacf-ca3c2371ef7b/1.2/borofloat33_therm_eng_web.pdf (accessed on 20 December 2019).

48. Bouras, N.; Madjoubi, M.A.; Kolli, M.; Benterki, S.; Hamidouche, M. Thermal and mechanical characterization of borosilicate glass. Phys. Procedia 2009, 2, 1135-1140. [CrossRef]

49. Suhonen, T.; Varis, T.; Dosta, S.; Torrell, M.; Guilemany, J.M. Residual stress development in cold sprayed Al, $\mathrm{Cu}$ and Ti coatings. Acta Mater. 2013, 61, 6329-6337. [CrossRef]

50. Miller, D.C.; Foster, R.R.; Jen, S.H.; Bertrand, J.A.; Cunningham, S.J.; Morris, A.S.; Lee, Y.C.; George, S.M.; Dunn, M.L. Thermo-mechanical properties of alumina films created using the atomic layer deposition technique. Sens. Actuators A Phys. 2010, 164, 58-67. [CrossRef]

(C) 2019 by the authors. Licensee MDPI, Basel, Switzerland. This article is an open access article distributed under the terms and conditions of the Creative Commons Attribution (CC BY) license (http://creativecommons.org/licenses/by/4.0/). 